\title{
Impact of DDT residues in feed on thyroid gland and liver secretory activity of Aberdeen-Angus cattle depending on cattle age and sex
}

\author{
A. Li' ${ }^{1}$, M. Derkho ${ }^{1}$, R. Tuyakova², P. Iwaniuk ${ }^{3}$ and B. Lozowicka ${ }^{3,4}$ \\ ${ }^{1}$ South Ural State Agrarian University, st. Gagarina 13, 457100, Troitsk, \\ Chelyabinsk Region, Russia \\ ${ }^{2}$ Republican Veterinary Laboratory of the Committee for Veterinary Control and Supervision of the Ministry of Agriculture of the \\ Republic of Kazachstan, st. Zarechnoye, Yubileynaya 5a, 111108, Kostanay, Kazachstan \\ ${ }^{3}$ Institute of Plant Protection - National Research Institute, Chełmońskiego 22, 15-195, Białystok, Poland
}

KEY WORDS: DDT, cattle, thyroid, liver, secretory activity

Received: $\quad 10$ April 2020

Revised: $\quad 26$ August 2020

Accepted: 30 November 2020

${ }^{4}$ Corresponding author:

e-mail: b.lozowicka@iorpib.poznan.pl

\begin{abstract}
Dichlorodiphenyltrichloroethane (DDT) and its metabolites are constantly detected in agricultural crops intended for animal feed. The aim of this study was to evaluate the impact of DDT residues in feed on thyroid gland and liver secretory activity of Aberdeen-Angus cattle depending on cattle age and sex. DDT (sum) concentration in the forage (milk, hay, silage, compound feed) and soil was determined by gas chromatography with micro electron capture selective detector (GC/ECD), while thyroid gland hormones (triiodothyronine (T3), thyroxine (T4)) concentrations and liver enzymes (alanine aminotransferase, aspartate aminotransferase, alkaline phosphatase, creatine kinase, lactate dehydrogenase) activities using ELISA, based on colorimetric method. It was indicated that natural contamination of soil and, in consequence, feed with DDT is diversed and was the highest in milk. Concentration of T3 decreased during bulls growth reaching the lowest level in 8-month animals (1.92 pmol/l), while content of T4 was raising and achieved the highest content in 8-month bulls (129.07 pmol/l). Opposite relation was observed in heifers (increasing content of T3 and falling level of T4). Liver enzymes activity was also depended on cattle age and sex. However, concentrations of thyroid hormones and activities of liver enzymes were significantly higher $(P<0.05)$ in bulls and heifers fed forage containing DDT. DDT contamination of feed leads to hypothyroid in bulls and hyperthyroid in heifers in long-term intake. Milk, which is given to the calves at the beginning of the nursing period should be especially examined for DDT residues occurrence because young animals are particularly susceptible to endocrine and liver disorders.
\end{abstract}

\section{Introduction}

Dichlorodiphenyltrichloroethane (DDT) is a chemical compound from organochlorines group. It was first synthesized in 1874, however its insecticidal activity against malaria and typhus was discovered during World War II. In the 1960s DDT was frequently used in high amounts as plant protection product all over the world (Mrema et al., 2013). DDT penetrates through the insect gastrointestinal tract or body surface and causes disruption of sodium channels functioning in nervous system (Du et al., 2015).

Due to its toxicology and long-time persistence in the environment, DDT was withdrawn in the 
1970s and 1990s in the developed countries, however, until now it is used in developing countries in malaria combating. It was examined that DDT residues contribute to neurotoxicity, hepatotoxicity, carcinogenicity, reproductive and endocrine disorders (Harada et al., 2016). Theoretical symptoms of acute DDT intoxication in humans are: increased excitability, impaired coordination, headaches, vomiting and convulsions, death due to respiratory paralysis and pulmonary oedema (Turusov et al., 2002). Taking under attention that DDT persistence in soil of temperate regions is estimated up to 30 years, these harmful effects are particularly relevant for environment, human and animal safety and despite its application ban, DDT is still determined in agricultural and animal products (Lozowicka et al., 2014; Lozowicka et al., 2015a).

In some parts of Asia, e.g. Kazakhstan, where DDT has been abandoned for more than 20 years, current incidents of organochlorines residues determination in cow's milk or meat are mostly related to plants and silages predicted for animal feed, which were grown on soils contaminated in the past by DDT (Snedeker, 2001; Kuba et al., 2015). Higher level of DDT residues in cow's milk may be connected with more severe soil, hay or feed components contamination (Aslam et al., 2013; Reddy and Reddy, 2015).

DDT belongs to endocrine disrupting chemicals (EDC), which compete with oestrogens and androgens for hormone binding receptors. It causes proliferation of androgen sensitive cells and stimulate creation of oestrogen receptors (Mnif et al., 2011). In consequence, DDT affects disruption of secretory activity of endocrine system in livestock, initiation of changes in their functional state and metabolic effects, demonstrated by chemical sterilization or embryo male feminization (Patisaul and Adewale, 2009). Thyroid hormones, triiodothyronine (T3) and thyroxine (T4), are activated by thyroid stimulating hormone (TSH), and are particularly responsible for growth, differentiation and metabolism regulation. T3 is an active form synthesized from prohormone T4 (Brix et al., 2011). Long-time exposure to DDT contributes to higher risk of hypothyroid disease occurrence in humans but thyroid secretory activity was poorly investigated in cattle divided to sex groups (Goldner et al., 2010; Yaglova and Yaglov, 2013). Due to the DDT occurrence in cattle feed, data showing its toxicological effects on detoxifying organs like liver are necessary. Harada et al. (2016), noticed that rats supplemented with feed containing DDT had higher liver mass and activity of microsomal cytochrome P450 and CYP2B1 enzymes. Similarly, activities of mice aspartate aminotransferase and alanine aminotransferase were higher after intake of feed supplemented with DDT (Arroyo-Salgado et al., 2016). Additionally, activation of lipid metabolism and initiation of fats infiltration on organ cells were observed.

In recent years, beef cattle breeding has been actively developing in the Republic of Kazakhstan. Until now, a large number of beef cattle breeds, including Aberdeen-Angus, had been brought into the country under the state funding program (Bozymov et al., 2012). Therefore, in Kazakhstan, the number of farms engaged in breeding cattle for beef production has increased. Although the cattle of the Aberdeen-Angus breed usually adapt well to environmental factors, in animals adjusting to the conditions of farms in Kazakhstan, the rising rate of metabolic disorders, manifested mostly in certain periods of physiological development, was observed. One of the reasons is the sensitivity of animal meat breeds to the quality of feed.

Assessment of the effect of residual amounts of organochlorine pesticides on the vital processes of the animals has not yet lost its relevance in modern biology. Taking under attention that most of human and animal organs are susceptible to plant protection product residues, fate examination of withdrawn organochlorines with particularly long-time persistence in the environment seems to be an important issue for health. So, the aim of this study was to evaluate the impact of DDT residues in feed on thyroid gland and liver secretory activity of AberdeenAngus cattle depending on cattle age and sex.

\section{Material and methods}

\section{Breeding cattle}

The experiment was conducted on the offspring of 40 mother cows of the Aberdeen-Angus breed, at the Kostanay Region, Republic of Kazakhstan. The first group of mother cows was fed for 12 months DDT-free forage and bred on farm with organochlorines residues-free soils. Second group of mother cows was fed for 12 months forage containing DDT residues and bred on farm with soil contaminated by organochlorine residues. The subject of the research were not mothers but their calves $(n=10$ male calves and $n=10$ female calves from the first group, and $n=10$ male calves and $n=10$ female calves from the second group). 
The experiment on thyroid and liver secretory activity determination started with cattle in the age of 1 month and finished in the age of 8 months, in 2017 and 2018. Bulls and heifers born from mother cows fed DDT-free forage were the first (control) group (fed milk, hay, silage, compound feed without DDT). Bulls and heifers born from mother cows fed forage containing DDT were the second experimental group (fed milk, hay, silage, compound feed containing DDT residues naturally occurring in the environment). Cattle in the first two weeks of life were fed $41 \mathrm{milk} /$ day. Up to three months of life cattle were fed $61 \mathrm{milk} /$ day and additionally $2 \mathrm{~kg}$ of grass-hay silage, with additional supplementation with hay and compound feed (barley-oat-wheat). In next days, up to month 8 of life they were fed grasshay silage $(10 \mathrm{~kg} /$ day $)$, hay $(2 \mathrm{~kg} /$ day $)$ and barleyoat-wheat compound feed ( $2 \mathrm{~kg}$ /day).

\section{Samples and reagents}

In this study 160 samples of milk (milk sample was collected once a week from mother fed forage containing DDT, for two months) were examined. Additionally, before trial, 8 samples of soil where the oat, barley and wheat grew, 8 samples of grass-hay silage, 8 samples of hay and 8 samples of barley-oat-wheat compound feed were collected. The research material consisted of samples from Kazakhstan, Kostanay Region. All samples have been obtained from local farmers according to ISO 24333:2009 (ISO, 2009). All organic solvents (acetonitrile, hexane, acetone) were supplied by SigmaAldrich (St. Louis, MO, USA). QuEChERS kits with buffering citrate salts (magnesium sulphate, sodium chloride $(\mathrm{NaCl})$, trisodium citrate dihydrate $\left(\mathrm{Na}_{3} \mathrm{C}_{6} \mathrm{H}_{5} \mathrm{O}_{7} * 2 \mathrm{H}_{2} \mathrm{O}\right)$, disodium hydrogen citrate sesquehydrate $\left.\left(\mathrm{Na}_{2} \mathrm{HC}_{6} \mathrm{H}_{5} \mathrm{O}_{7} * 1.5 \mathrm{H}_{2} \mathrm{O}\right)\right)$ were obtained from Agilent Technologies (Santa Clara, CA, USA). The commercial sorbents $\mathrm{PSA} / \mathrm{C} 18 / \mathrm{MgSO}_{4}$ and $\mathrm{PSA} / \mathrm{GBC} / \mathrm{MgSO}_{4}$, formic and sulphate acid were purchased from Sigma-Aldrich (Steinheim, Germany) and Florisil (60-100 mesh) from J.T. Baker (Deventer, Holland).

Pesticide standards: 2,4'-DDT, 4,4'-DDT, 2, 4'-DDD, 4,4'-DDD, 2,4'-DDE, 4,4'-DDE were obtained from the Dr. Ehrenstorfer Laboratory (Wesel, Germany). Pesticide standard stock solutions (purity for all standards $>95 \%$ ) of various concentrations were prepared in acetone and stored at $4{ }^{\circ} \mathrm{C}$. Standard working solutions were prepared by dissolving $1 \mathrm{ml}$ of stock solution with a mixture hexane/acetone $(9: 1 ; \mathrm{v} / \mathrm{v})$.

\section{Preparation of soil, hay, silage and compound feed samples}

The samples for DDT residues determination were prepared according to Lozowicka et al. (2015b), with some modifications. The homogenized sample ( $10 \mathrm{~g}$ soil; $2 \mathrm{~g}$ hay; $5 \mathrm{~g}$ silage and $5 \mathrm{~g}$ compound feed) was weighed in a 50-ml centrifuge tube. Then, $5 \mathrm{ml}$ deionized water was added and the mixture was gently shaken for several seconds. Subsequently, $10 \mathrm{ml}$ acetonitrile with $1 \%$ formic acid, $1 \mathrm{~g}$ sodium chloride, $4 \mathrm{~g}$ magnesium sulphate, $0.5 \mathrm{~g}$ disodium hydrogencitrate sesquihydrate and $1 \mathrm{~g}$ trisodium citrate dihydrate (commercial kit) were added. The samples were shortly vortexed and centrifuged for $5 \mathrm{~min}$ at $5000 \mathrm{rpm}$. Supernatant $(5 \mathrm{ml})$ was transferred into a new centrifuge tube containing purifying agent: (a) $500 \mathrm{mg}$ of florisil (soil); (b) $25 \mathrm{mg}$ PSA $+150 \mathrm{mg} \mathrm{GBC}+2.5 \mathrm{~g} \mathrm{MgSO}_{4}$ (hay); (c) $25 \mathrm{mg}$ PSA $+150 \mathrm{mg} \mathrm{C} 18+2.5 \mathrm{~g} \mathrm{MgSO}_{4}$ (silage and compound feed). Mixed solution was centrifuged at $5000 \mathrm{rpm}$ for $1 \mathrm{~min}$. Supernatant $(1 \mathrm{ml})$ was filtered through $0.45-\mu \mathrm{m}$ membrane filter into vial for gas chromatography (GC) analysis.

\section{Preparation of milk samples}

Milk samples for DDT residues determination were prepared according to Zheng et al. (2014), with some modifications. Milk (10 g) was weighed in a 50-ml centrifuge tubes. For each sample $1 \mathrm{ml} 0.5 \mathrm{M}$ $\mathrm{H}_{2} \mathrm{SO}_{4}$ was added and mixed by hand for $1 \mathrm{~min}$. After $5 \mathrm{~min}, 10 \mathrm{ml}$ acetonitrile was added, vortexed for $1 \mathrm{~min}$ and then mixtures were kept in freezer for 15-min. Mix of $1 \mathrm{~g}$ sodium chloride, $4 \mathrm{~g}$ magnesium sulphate, $0.5 \mathrm{~g}$ disodium hydrogencitrate sesquihydrate and $1 \mathrm{~g}$ trisodium citrate dihydrate (commercial kit) was added and the tubes were mixed by hand for $1 \mathrm{~min}$. The samples were centrifuged for $5 \mathrm{~min}$ at $4500 \mathrm{rpm}$. The acetonitrile layer was transferred into a $15 \mathrm{ml}$ centrifuge tubes and kept in the low temperature freezer for $30 \mathrm{~min}$. Extract $(1 \mathrm{ml})$ was filtered through $0.45-\mu \mathrm{m}$ membrane filter into vial for $\mathrm{GC}$ analysis.

\section{Instrumentation and chromatographic conditions}

Quantitative estimation of DDT residues in extracts by an Agilent 7890 gas chromatograph (Santa Clara, CA, USA) equipped with a Model HP 7683 automatic split-splitless injector, a ${ }^{63} \mathrm{Ni}$ micro electron capture detector $(\mu \mathrm{EC})$, was done. Data acquisition and processing with a Chemstation (HewlettPackard, version A.10.2, Palo Alto, USA) software were performed. The DB-35, a midpolarity fused 
silica column (35\%-phenyl)-methylpolysiloxane with low bleed $(30 \mathrm{~m} \times 0.32 \mathrm{~mm}$ I.D. $\times 0.5 \mu \mathrm{m}$ film thickness), supplied by Agilent (Little Falls, DE, USA) was used. Helium as a carrier gas at a constant flow of $1.9 \mathrm{ml} / \mathrm{min}$ and a nitrogen as make-up gas (57 ml/min), hydrogen $3.0 \mathrm{ml} / \mathrm{min}$ and air $60 \mathrm{ml} / \mathrm{min}$ were used. Details of gas operating parameters were as follows: the injector and detector temperatures: $300{ }^{\circ} \mathrm{C}$, oven programme: initial temperature $120^{\circ} \mathrm{C}$ increased to $190{ }^{\circ} \mathrm{C}$ at $13{ }^{\circ} \mathrm{C} / \mathrm{min}$, then to $240{ }^{\circ} \mathrm{C}$ at $8{ }^{\circ} \mathrm{C} / \mathrm{min}$ and finally to $295{ }^{\circ} \mathrm{C}$ at $168{ }^{\circ} \mathrm{C} / \mathrm{min}$ and held for $20 \mathrm{~min}$. Sample $(2 \mu \mathrm{l})$ was injected at $210^{\circ} \mathrm{C}$ in splitless mode (purge off time $2 \mathrm{~min}$ ). Total time of analysis: $35 \mathrm{~min}$ and equilibration time: $2 \mathrm{~min}$. Individual DDTs were identified by comparison of retention time between samples and the standard solution. For positive peaks of pesticides detected above the results were confirmed by gas chromatography coupled with tandem mass spectrometry (GC-MS/MS).

\section{Validation of the method}

The validation study was carried out using soil, hay, silage and feed samples previously checked to be free of DDT. Blank samples (2-10 g) after homogenization (Document No. SANTE/11813/2017) were spiked by addition of appropriate volumes of pesticide standard mixture in solution hexane/acetone $(9: 1, \mathrm{v} / \mathrm{v})$, kept for $1 \mathrm{~h}$ (equilibration time) and then prepared according to the procedure described above. The parameters: matrix effect, linearity, limits of detection (LOD) and quantification (LOQ), recovery and precision were evaluated. Calibration curves were obtained from matrix-matched multi-level calibration solutions. Calibration standards were prepared by adding the respective spiking solutions to a blank matrix of soil, hay, silage and compound feed to obtain final concentration of $0.001,0.05,0.1,0.5,2.0 \mathrm{mg} / \mathrm{kg}$ for GC. Linearity was determined from the coefficients of determination $\left(\mathrm{R}^{2}\right)$. The LOQ and LOD were evaluated as the signal-to-noise ratios $(\mathrm{S} / \mathrm{N})$ of $10: 1$ and 3:1 for the pesticide, respectively.

\section{Determination of thyroid hormones concentrations}

Blood at the volume of $20 \mathrm{ml}$ was collected by syringe from the tail vein of cattle at 1, 3, 6 and 8 month of age, before morning feeding. Next, 20 Units of heparin (Sigma-Aldrich, St. Louis, MO, USA) per $1 \mathrm{ml}$ of blood was added and vortexed. Samples were centrifuged at $10000 \mathrm{rpm}$ for $15 \mathrm{~min}$ at $4{ }^{\circ} \mathrm{C}$ within $30 \mathrm{~min}$ from the collection. The serum was collected into the test tubes and kept at $-20{ }^{\circ} \mathrm{C}$ until further use. The level of thyroid hormones (triiodothyronine (T3) and thyroxine (T4)) was determined according to commercial kits (LifeSpan Sciences, Seattle, WA, USA) using ELISA method.

ELISA plate was washed two times for 2 min. using $350 \mu 1$ of a Washing Buffer and then totally dried. For appropriate wells $50 \mu 1$ of standard, blank and sample solutions were added followed by $50 \mu 1$ of a Biotinylated Standard for T3 or a Biotin Detection Antibody solution for T4 detection. The plate was covered by seal and gently agitated at $37^{\circ} \mathrm{C}$ for $60 \mathrm{~min}$ (T3) or $45 \mathrm{~min}$ (T4). Plate was washed three times using Washing Buffer and $50 \mu 1$ HRP-Avidin Conjugate (T3) or $100 \mu 1$ HRPStreptavidin Conjugate (T4). Plate was seal-covered and incubated at $37^{\circ} \mathrm{C}$ for $30 \mathrm{~min}$. Next, plate was washed five times using Washing Buffer and $90 \mu 1$ of substrate was added to each well. Plate was incubated at $37^{\circ} \mathrm{C}$ for $20 \mathrm{~min}$ followed by $50 \mu \mathrm{l}$ of a Stop Solution and incubation at $37^{\circ} \mathrm{C}$ for $20 \mathrm{~min}$. Absorbance was read at the wavelength of $450 \mathrm{~nm}$ (T3) or $405 \mathrm{~nm}$ (T4) at a GloMax-Multi Microplate Multimode Reader (Promega, Walldorf, Germany) and calculated according to standard solution calibration curve as the pmol of hormone/l of blood.

\section{Determination of liver enzymes activity}

The activities of liver enzymes: alanine aminotransferase (AlAT), aspartate aminotransferase (AcAT), alkaline phosphatase (ALP), creatine kinase $(\mathrm{CK})$, lactate dehydrogenase $(\mathrm{LDH})$ were assesed. Blood $(20 \mathrm{ml})$ from tail vein was collected in the same way as for thyroid hormones activity estimation and serum was kept at $-20{ }^{\circ} \mathrm{C}$ until further use. All enzymes activities were assayed from serum using ELISA method according to manufacturer instructions (LifeSpan Sciences, Seattle, WA, USA). The absorbance of all enzymes was read at a wavelength of $450 \mathrm{~nm}$ at the GloMax-Multi Microplate Multimode Reader (Promega, Walldorf, Germany) and calculated according to standard solution calibration curves as the unit (U) of enzyme/l of blood.

\section{Statistical analyses}

The obtained results were subjected to basic statistical analysis using the STATISTICA 12 software (StatSoft, Tulsa, USA). In addition, the effect of DDT (sum) on biological activity parameters was determined using one-way analysis of ANOVA variance. Significant differences were assessed by Tukey's test at the significance level of $P<0.05$. Additionally, Pearson's correlation coefficients (r) between the level of DDT (sum) in feed and thyroid hormones concentration, and liver enzymes activities in blood were determined. 


\section{Results}

\section{Method validation}

In this study, soil, hay, silage, milk and compound feed samples free of pesticides were used for the validation of the method in determination of DDT and metabolites residue. Recoveries of all pesticides were tested by fortifying (Document No. SANTE/11813/2017) blank sample (milk, soil, hay, silage and compound feed) with pesticide mixture (a final spikes concentration of $1^{\text {st }}$ range $0.001-0.05 \mathrm{mg} / \mathrm{kg}, 2^{\text {nd }}$ range $0.1-0.5 \mathrm{mg} / \mathrm{kg}$ and $3^{\text {rd }}$ range $0.5-2.0 \mathrm{mg} / \mathrm{kg}$ ). Linearity was evaluated through analysis of five standard solutions, in five replicates, within $0.01-2.0 \mu \mathrm{g} / \mathrm{ml}$. Standards calibration showed satisfactory linearity within the studied range, with correlation coefficients $(r) \geq 0.995$. Accuracy (percentage recoveries) and precision (repeatability, $\%$ RSD) were estimated by recovery experiments in the soil, hay, silage, milk and compound feed matrices under study, at five fortification levels $0.001,0.05$, $0.1,0.5,2.0 \mathrm{mg} / \mathrm{kg}$, each one analysed in quintuplicate. The obtained results were satisfactory for DDT and metabolites in each matrix, with recoveries 88.8$95.0 \%$ and precision below $15 \%$. The LOQs were defined as the minimum concentration of the analyse that can be quantified with acceptable accuracy and precision. The LODs were estimated for a signal-tonoise ratio of 3 from the chromatograms of samples spiked at the lowest validated concentration, i.e., $0.001 \mathrm{mg} / \mathrm{kg}$. For GC estimated LODs were $0.001 \mathrm{mg} /$ $\mathrm{kg}$ for all compounds. The validated method was applied to the analysis of real samples from the experiment.

\section{Soil and feed contamination with DDT residues}

Natural contamination of feed with DDT and metabolites is diverse and depends on the type of the forage. Maximal concentration of organochlorines among feed types was detected in milk $(0.029 \mathrm{mg} / \mathrm{kg})$ (Table 1). In hay, grass-hay silage and compound feed comparable level of organochlorine residues (up to $0.010 \mathrm{mg} / \mathrm{kg}$ ) was noted (Table 2). However, the highest concentration of DDT sum was detected in soil samples (up to $0.289 \mathrm{mg} / \mathrm{kg}$ ).

\section{Thyroid hormones concentration}

Thyroid hormones were synthesized in diversified levels depending on the age of the cattle, sex and presence of DDT residues in feed. Concentration of T3 (Table 3) in control group of cattle fed DDT-free forage decreased during bulls growth,
Table 1. The average content of dichlorodiphenyltrichloroethane (DDT) and its metabolites in milk from mothers fed forage containing DDT residues (each -8 samples)

\begin{tabular}{|c|c|c|c|c|c|c|c|}
\hline \multirow[b]{2}{*}{$\begin{array}{l}\text { No. of } \\
\text { mother }\end{array}$} & \multicolumn{7}{|c|}{ DDT and its metabolites in milk, $\mathrm{mg} / \mathrm{kg}$} \\
\hline & $\begin{array}{l}2,4^{\prime}- \\
\text { DDT }\end{array}$ & $\begin{array}{l}4,4^{\prime}- \\
\text { DDT }\end{array}$ & $\begin{array}{l}2,4^{\prime}- \\
\text { DDD }\end{array}$ & $\begin{array}{l}4,4^{\prime}- \\
\text { DDD }\end{array}$ & $\begin{array}{l}2,4 '- \\
\text { DDE }\end{array}$ & $\begin{array}{l}4,4^{\prime}- \\
\text { DDE }\end{array}$ & $\begin{array}{l}\text { DDT } \\
\text { sum }\end{array}$ \\
\hline 1 & 0.001 & 0.005 & 0.001 & & 0.002 & 0.006 & 0.015 \\
\hline 2 & 0.001 & 0.004 & & 0.002 & & 0.011 & 0.018 \\
\hline 3 & & 0.006 & 0.001 & 0.003 & 0.001 & 0.011 & 0.022 \\
\hline 4 & 0.001 & 0.002 & 0.003 & 0.002 & & 0.012 & 0.020 \\
\hline 5 & & 0.004 & & 0.003 & 0.001 & 0.012 & 0.020 \\
\hline 6 & & 0.002 & & 0.004 & & 0.012 & 0.018 \\
\hline 7 & 0.003 & 0.007 & 0.001 & 0.003 & & 0.010 & 0.024 \\
\hline 8 & & 0.002 & & 0.002 & & 0.011 & 0.015 \\
\hline 9 & & 0.004 & & 0.003 & & 0.009 & 0.016 \\
\hline 10 & & 0.003 & & & 0.001 & 0.006 & 0.010 \\
\hline 11 & 0.001 & 0.002 & & 0.004 & & 0.009 & 0.016 \\
\hline 12 & & 0.006 & 0.003 & 0.003 & & 0.010 & 0.022 \\
\hline 13 & 0.001 & 0.004 & & 0.002 & & 0.009 & 0.016 \\
\hline 14 & & 0.008 & 0.001 & 0.003 & 0.003 & 0.014 & 0.029 \\
\hline 15 & & 0.007 & & 0.003 & & 0.014 & 0.024 \\
\hline 16 & & 0.003 & & 0.005 & & 0.010 & 0.018 \\
\hline 17 & & & 0.001 & 0.003 & & 0.009 & 0.013 \\
\hline 18 & 0.002 & 0.003 & & & & 0.009 & 0.014 \\
\hline 19 & & 0.005 & & 0.003 & 0.001 & 0.009 & 0.018 \\
\hline 20 & & 0.007 & & 0.005 & & 0.014 & 0.026 \\
\hline Mean & 0.002 & 0.004 & 0.002 & 0.003 & 0.002 & 0.010 & 0.019 \\
\hline
\end{tabular}

2,4'-DDT - 1,1,1-trichloro-2-(2-chlorophenyl)-2-(4-chlorophenyl)ethane, 4,4'-DDT - 1,1,1-trichloro-2,2-bis(4-chlorophenyl)ethane, 2,4'-DDD - (2,4'-dichlorodiphenyl)dichloroethane, 4,4'-DDD - 1,1-dichloro-2,2bis(4-chlorophenyl)ethane, 2,4'-DDE - 2-(2-chlorophenyl)-2-(4chlorophenyl)-1,1-dichloroethene, 4,4'-DDE - 1,1-dichloro-2,2-bis(4chlorophenyl)ethene

Table 2. The content of dichlorodiphenyltrichloroethane (DDT) (sum) in soil and feed

\begin{tabular}{lll}
\hline Soil/type of feed & $\begin{array}{l}\text { Average DDT (sum) } \\
\text { content, mg/kg }\end{array}$ & $\begin{array}{l}\text { DDT (sum) content } \\
\text { range, mg/kg }\end{array}$ \\
\hline Soil & $0.198 \pm 0.013$ & $0.128-0.289$ \\
Hay & $0.008 \pm 0.003$ & $0.005-0.010$ \\
Grass-hay silage & $0.007 \pm 0.001$ & $0.005-0.009$ \\
$\begin{array}{l}\text { Compound feed } \\
\text { (barley-oat-wheat) }\end{array}$ & $0.006 \pm 0.002$ & $0.005-0.008$ \\
\hline
\end{tabular}

reaching minimal concentration in 8-month old animals $(1.92 \mathrm{pmol} / \mathrm{l})$. T3 level in heifers fed control feed increased during their growth and jumped to the highest concentration in 8-month-old animals ( $2.80 \mathrm{pmol} / \mathrm{l})$. Opposite relation was observed for T4. In bulls, T4 content increased during growth, while in heifers it was lower and reached minimal concentration in 8-month-old animals (43.64 pmol/1). 
Table 3. The content of thyroid hormones in the blood of calves

\begin{tabular}{|c|c|c|c|c|}
\hline \multirow{2}{*}{ Indices } & \multicolumn{4}{|c|}{ Calves age, months } \\
\hline & 1 & 3 & 6 & 8 \\
\hline \multicolumn{5}{|l|}{ Triiodothyronine (T3), pmol/l } \\
\hline bulls (DDT-free feed) & $3.07^{c}$ & $2.65^{c}$ & $2.34^{\mathrm{a}}$ & $1.92^{\mathrm{a}}$ \\
\hline bulls (feed with DDT) & $3.49^{d}$ & $3.02^{d}$ & $2.72^{\mathrm{bc}}$ & $2.46^{b}$ \\
\hline heifers (DDT-free feed) & $1.52^{\mathrm{a}}$ & $1.89^{\mathrm{a}}$ & $2.56^{b}$ & $2.80^{\circ}$ \\
\hline heifers (feed with DDT) & $1.97^{b}$ & $2.38^{b}$ & $2.98^{c}$ & $3.26^{d}$ \\
\hline \multicolumn{5}{|l|}{ Thyroxine (T4), pmol/l } \\
\hline bulls (DDT-free feed) & $51.73^{\mathrm{a}}$ & $66.24^{b}$ & $93.52^{c}$ & $129.07^{c}$ \\
\hline bulls (feed with DDT) & $53.35^{b}$ & $68.90^{\circ}$ & $95.90^{\mathrm{d}}$ & $131.77^{\mathrm{d}}$ \\
\hline heifers (DDT-free feed) & $71.76^{c}$ & $62.65^{\mathrm{a}}$ & $51.81^{\mathrm{a}}$ & $43.64^{\mathrm{a}}$ \\
\hline heifers (feed with DDT) & $74.41^{\mathrm{d}}$ & $65.17^{b}$ & $54.02^{\mathrm{b}}$ & $46.11^{b}$ \\
\hline \multicolumn{5}{|l|}{ T4/T3 ratio } \\
\hline bulls (DDT-free feed) & $16.85^{\mathrm{a}}$ & $24.99^{b}$ & $39.96^{\mathrm{d}}$ & $67.22^{c}$ \\
\hline bulls (feed with DDT) & $15.28^{a}$ & $22.81^{\mathrm{a}}$ & $35.26^{c}$ & $53.57^{b}$ \\
\hline heifers (DDT-free feed) & $47.21^{c}$ & $33.14^{d}$ & $15.60^{\mathrm{a}}$ & $15.58^{\mathrm{a}}$ \\
\hline heifers (feed with DDT) & $37.77^{\mathrm{b}}$ & $27.38^{c}$ & $18.13^{b}$ & $14.14^{\mathrm{a}}$ \\
\hline
\end{tabular}

T4/T3 ratio was lower (3.50 and 2.67 for bulls and heifers, respectively).

Under the conditions of the physiological state in the animal organism, the hormones of the thyroid gland provide the rate of anabolic reactions and growth processes. In order to assess the role of organochlorines entering the body by the alimentary tract on the thyroid secretion activity, Pearson's correlation coefficients were calculated. The strongest correlation was noticed for DDT sum residues in milk and thyroid hormones concentrations depending on cattle sex. Other types of forage did not influence thyroid hormones significantly $(\mathrm{r}<0.5)$. Positive correlation was determined for DDT in milk and T3 $(r=0.74)$ or T4 $(r=0.88)$ in heifers or bulls, respectively. Negative relation was observed for DDT in milk and T3 $(r=-0.73)$ or T4 $(\mathrm{r}=-0.77)$ in bulls or heifers, respectively (Table 4).

Table 4. Pearson's correlation coefficients between dichlorodiphenyltrichloroethane (DDT) residues in milk, forage and thyroid gland hormones concentrations and liver enzymes activities in calves: bulls $(B)$ or heifers $(H)$

\begin{tabular}{|c|c|c|c|c|c|c|c|c|c|c|c|c|c|c|c|c|}
\hline Indices & $\begin{array}{l}\text { T3 } \\
B\end{array}$ & $\begin{array}{l}\text { T3 } \\
\mathrm{H}\end{array}$ & $\begin{array}{l}\text { T4 } \\
\mathrm{B}\end{array}$ & $\begin{array}{l}\text { T4 } \\
\mathrm{H}\end{array}$ & $\begin{array}{l}\mathrm{T} 4 / \mathrm{T} 3 \\
\mathrm{~B}\end{array}$ & $\begin{array}{l}\text { T4/T3 } \\
\mathrm{H}\end{array}$ & $\begin{array}{l}\text { AlAT } \\
\text { B }\end{array}$ & $\begin{array}{l}\text { AIAT } \\
\mathrm{H}\end{array}$ & $\begin{array}{l}\text { AcAT } \\
\text { B }\end{array}$ & $\begin{array}{l}\text { AcAT } \\
\mathrm{H}\end{array}$ & $\begin{array}{l}\text { ALP } \\
\text { B }\end{array}$ & $\begin{array}{l}\text { ALP } \\
\mathrm{H}\end{array}$ & $\begin{array}{l}\mathrm{CK} \\
\mathrm{B}\end{array}$ & $\begin{array}{l}\mathrm{CK} \\
\mathrm{H}\end{array}$ & $\begin{array}{l}\mathrm{LDH} \\
\mathrm{B}\end{array}$ & $\begin{array}{l}\mathrm{LDH} \\
\mathrm{H}\end{array}$ \\
\hline DDT in milk & $-0.73^{*}$ & $0.74^{*}$ & $0.88^{*}$ & $-0.77^{*}$ & $0.89^{*}$ & $-0.68^{*}$ & -0.38 & 0.04 & -0.20 & 0.35 & $-0.71^{*}$ & $-0.85^{\star}$ & 0.47 & $0.61^{*}$ & $0.89^{*}$ & $0.85^{*}$ \\
\hline DDT in hay & 0.47 & -0.34 & -0.43 & 0.39 & -0.44 & 0.39 & 0.31 & 0.09 & 0.42 & 0.12 & 0.31 & 0.48 & -0.46 & -0.42 & $-0.64^{*}$ & -0.46 \\
\hline $\begin{array}{l}\text { DDT in grass-hay } \\
\text { silage }\end{array}$ & -0.14 & 0.30 & 0.36 & -0.28 & 0.35 & -0.19 & -0.07 & 0.09 & 0.22 & 0.44 & -0.31 & -0.26 & -0.10 & 0.07 & 0.12 & 0.29 \\
\hline $\begin{array}{l}\text { DDT in compound } \\
\text { feed }\end{array}$ & 0.16 & -0.37 & -0.38 & 0.30 & -0.31 & 0.24 & 0.10 & 0.12 & -0.28 & -0.42 & 0.37 & 0.29 & 0.15 & -0.11 & -0.16 & -0.35 \\
\hline
\end{tabular}

T3 - triiodothyronine, T4 - thyroxine, AIAT - alanine aminotransferase, ACAT - aspartate aminotransferase, ALP - alkaline phosphatase, CK - creatine kinase, LDH - lactate dehydrogenase; * - indicates statistical significance at $P<0.05$

Additionally, the concentration of thyroid hormones was changed in cattle fed forage contained DDT residues but also depended on animal sex. T3 reached the highest level in 1-month-old bulls $(3.49 \mathrm{pmol} / \mathrm{l})$ and its content decreased during growth achieving the lowest value in 8-monthold bulls. For heifers opposite relation was observed - T3 level increased during animal growth. The highest concentration was observed in 1-month old heifers $(74.41 \mathrm{pmol} / \mathrm{l})$ and its content was gradually lowering during heifers age, reaching the minimum concentration in 8-month-old females (Table 3 ). For bulls, the content of T4 increased during growth and achieved the highest level in 8-month old males (131.77 pmol/1).

During the bulls growth, the bioconversion of thyroid hormones measured as T4/T3 ratio increased 3.99 times $(P<0.05)$, in contrast to heifers where 3.03 times decrease was observed. Interestingly, in animals fed forage contaminated by DDT residues

\section{Liver enzymes activities}

The lowest activity of liver enzymes in cattle fed control forage was determined for AlAT (14.2 U/1). Liver enzymes activity increased during cattle growth, reaching maximal level in 6- or 8-month-old calves (up to $1387 \mathrm{U} / 1$ for LDH). The exception was ALP. Its content decreased during cattle growth and was detected in the greatest amount in 1-month-old calves. Average activity of liver enzymes was higher in heifers (Table 5).

Liver enzymes activity in cattle fed DDTcontaining forage was higher than in calves fed control feed. However, the most significant correlation was determined for level of DDT residues in milk with $\mathrm{LDH}$ and $\mathrm{CK}(\mathrm{r}=0.89$ and $r=0.61$, respectively). DDT values from other types of forage did not correlated significantly with liver enzymes activity. In comparison to bulls, the highest values of liver enzymes, except AlAT and AcAT, were noted in heifers (Table 5). 
Table 5. Liver enzymes activities in the blood of cattle

\begin{tabular}{|c|c|c|c|c|}
\hline \multirow{2}{*}{ Indices } & \multicolumn{4}{|c|}{ Calves age, months } \\
\hline & 1 & 3 & 6 & 8 \\
\hline \multicolumn{5}{|c|}{ Alanine aminotransferase (AIAT), U/I } \\
\hline bulls (DDT-free feed) & $16.4^{\mathrm{b}}$ & $39.6^{\mathrm{ab}}$ & $71.8^{\mathrm{a}}$ & $21.5^{\mathrm{a}}$ \\
\hline bulls (feed with DDT) & $18.5^{c}$ & $42.0^{\circ}$ & $73.7^{b}$ & $23.0^{b}$ \\
\hline heifers (DDT-free feed) & $14.2^{\mathrm{a}}$ & $38.4^{\mathrm{a}}$ & $71.9^{\mathrm{a}}$ & $41.0^{c}$ \\
\hline heifers (feed with DDT) & $16.9^{b}$ & $40.0^{\mathrm{b}}$ & $74.0^{\mathrm{b}}$ & $43.0^{\mathrm{d}}$ \\
\hline \multicolumn{5}{|c|}{ Aspartate aminotransferase (AcAT), U/l } \\
\hline bulls (DDT-free feed) & $76.3^{c}$ & $79.7^{\mathrm{a}}$ & $91.6^{\mathrm{a}}$ & $79.1^{\mathrm{a}}$ \\
\hline bulls (feed with DDT) & $79.6^{\mathrm{d}}$ & $82.3^{b}$ & $94.7^{b}$ & $82.0^{b}$ \\
\hline heifers (DDT-free feed) & $68.6^{\mathrm{a}}$ & $71.3^{c}$ & $92.2^{\mathrm{a}}$ & $84.4^{c}$ \\
\hline heifers (feed with DDT) & $71.8^{\mathrm{b}}$ & $75.0^{\mathrm{d}}$ & $95.0^{\mathrm{b}}$ & $87.0^{d}$ \\
\hline \multicolumn{5}{|c|}{ Alkaline phosphatase (ALP), U/l } \\
\hline bulls (DDT-free feed) & $510^{a}$ & $475^{a}$ & $423^{b}$ & $405^{b}$ \\
\hline bulls (feed with DDT) & $515^{b}$ & $482^{b}$ & $430^{\mathrm{d}}$ & $411^{c}$ \\
\hline heifers (DDT-free feed) & $594^{c}$ & $504^{c}$ & $419^{a}$ & $297^{a}$ \\
\hline heifers (feed with DDT) & $600^{d}$ & $510^{d}$ & $425^{c}$ & $302^{\mathrm{a}}$ \\
\hline \multicolumn{5}{|l|}{ Creatine kinase (CK), U/l } \\
\hline bulls (DDT-free feed) & $100^{\mathrm{a}}$ & $163^{a}$ & $183^{a}$ & $183^{a}$ \\
\hline bulls (feed with DDT) & $106^{b}$ & $170^{b}$ & $190^{b}$ & $190^{\mathrm{b}}$ \\
\hline heifers (DDT-free feed) & $138^{c}$ & $188^{c}$ & $218^{c}$ & $228^{c}$ \\
\hline heifers (feed with DDT) & $145^{d}$ & $195^{\mathrm{d}}$ & $225^{d}$ & $234^{d}$ \\
\hline \multicolumn{5}{|c|}{ Lactate dehydrogenase (LDH), U/I } \\
\hline bulls (DDT-free feed) & $1002^{\mathrm{a}}$ & $1078^{a}$ & $1095^{a}$ & $1200^{\mathrm{a}}$ \\
\hline bulls (feed with DDT) & $1009^{c}$ & $1085^{b}$ & $1100^{b}$ & $1206^{a}$ \\
\hline heifers (DDT-free feed) & $1104^{b}$ & $1185^{c}$ & $1273^{c}$ & $1387^{\mathrm{b}}$ \\
\hline heifers (feed with DDT) & $1111^{d}$ & $1191^{\mathrm{d}}$ & $1279^{c}$ & $1395^{b}$ \\
\hline
\end{tabular}

DDT - dichlorodiphenyltrichloroethane, ${ }^{a-d}$ - the same letter in the age group indicates not statistically significant value $(P>0.05)$

\section{Discussion}

In the nursing period, one of the main components of the diet of young animals is the milk of mother cows, the biological and nutritional value of which determines the rate of growth and development of young animals (Kertz et al., 2017). Despite the fact that DDT has been no longer used in agriculture in the Republic of Kazakhstan for more than 20 years, the organochlorine pesticide was determined in soil, milk, hay, grass-hay silages and barley-oat-wheat compound feed, which indicates high persistence of this compound in the soil and low rate of dissipation. According to Pesticides Properties Data Base (PPDB), average half-time of DDT in soil is almost 17 years and due to high contamination of soil, organochlorines are still detected in agricultural products and are accumulated in milk originating from cows fed forage containing DDT residues and concentrate in fat rich products. Despite that maximum allowed DDT residue levels are $0.04 \mathrm{mg} / \mathrm{kg}$ for milk and $0.05 \mathrm{mg} / \mathrm{kg}$ for cereals in compound feed
(European Comission Regulation No. 149/2008), the highest organochlorine concentration in our study was $0.029 \mathrm{mg} / \mathrm{kg}$ (determined in milk).

Although the level of feed contamination is acceptable by EU, taking under attention the daily intake of DDT in feed, its concentration may be sufficient to influence the state of physiological systems in the body of calves as a result of impaired barrier function of the gastrointestinal tract and metabolic disorders in tissues and organs. Thyroid gland was selected as a marker of the effect of DDT residual amounts on animals, since the DDT is endocrine disruptor (Calsolaro et al., 2017). In addition, thyroid hormones in the body of young animals have a general metabolic effect, which is associated with their ability to penetrate the lipophilic layer of the cell membrane and interact with steroid hormone receptors in the nucleus, affecting gene expression. Hormone receptors can also bind to DDT molecules, responding to them with a hormone-like effect, which affects changed secretory activity of the thyroid gland (Mughal et al., 2018; Leemans et al., 2019). However, the impact of organochlorines on thyroid secretion activity may diversely lead to hypothyroid (in rats (Tebourbi et al., 2010) or grey seals (Sormo et al., 2005)) or hyperthyroid (in cats (Engadahl et al., 2017) or pigeons (Shrestha et al. (2018)).

It was shown that thyroid hormones dynamics in the blood of young animals depend on age and sex of the animal as well as on DDT intake with feed. The level of T4 in the body of 8-monthold bulls exceeded its initial value by 2.50 times for control or 2.46 times for DDT occurrence $(P<0.05)$. This indicated the activation of the secretory activity of thyrocytes as a result of either an increase in the content of colloid in the thyroid cells or an increase in the number of thyroid follicles (Colin et al., 2013). At the same time, the concentration of T3 in the blood of bulls decreased due to the decrease in the rate of prohormone T4 conversion into the active form (T3) as measured by the value of the T4/T3 ratio. In heifers the opposite age dynamics of thyroid hormones was observed. The T4 concentration decreased with age (1.64 times for control or 1.61 times for DDT occurrence; $P<0.05)$ against an increase in the level of T3 (1.84 times for control or 1.65 times for DDT occurrence; $P<0.05$ ) as a result of an increase in the rate of $\mathrm{T} 4$ to $\mathrm{T} 3$ bioconversion (Table 3). It was observed that secretory activity of thyrocytes increased in heifers, providing effective resorption of the colloid. There are little research 
showing differences in thyroid secretion activity depending on cattle sex and development. Heifers of the Holstein breed have lower levels of T3 and T4 in comparison to bulls, however, in both sex, thyroid hormones concentration increase during cattle growth (Kahl and Bitman, 1983). Medica et al. (2020) noticed in Brown calves fed only milk that T3 level declined in cattle until 2 month of life, while T4 concentration increased until 6 month of life with no differences related to cattle sex. Significant differences in thyroid hormones concentration between bulls and heifers in our study are connected with different breed of cattle (Aberdeen-Angus) and more complex feed, including milk, hay, silage, compound feed.

Beside thyroid hormones, the activity of liver enzymes depend on the age and sex of animals (Miles et al., 2015). However, due to the detoxifying role of liver, its status is related to the activity of liver enzymes, which increased activity indicates health problems. Our results showed that DDT residues presence in the feed caused liver disorders, reflected in increased activity of enzymes in comparison to control group. Maximal activity of enzymes was detected in 6-month-old cattle, except $\mathrm{LDH}$, indicating the dependence of the exchange of free amino acids on the age of young animals. In this case, the enzymatic activity was significantly higher in heifers than in bulls, except AlAT and AcAT, reflecting the effect of sex on the metabolism of amino acids, which was poorly investigated for cattle. Prolonged exposure on DDT residues caused elevated activity of liver enzymes, which can interfere with normal metabolic processes and contribute to metabolic syndrome (Perera et al., 2008). There was noticed that some pesticides can contribute to steatosis, hepatitis or cancer in rodents, which are preceded by increased activity of liver enzymes (Al-Eryani et al., 2014) but it was poorly investigated for calves. Due to the greatest DDT content in milk, the most effective increase of liver enzymes activity was observed in cattle to 6 month of life, thus young animals are most exposed to metabolic disorders despite further feeding with DDT-containing forage. Contaminated milk intended for sale as main source of organochlorines may contribute to metabolic disorders in humans in long term intake. Higher activity of enzymes in bulls than heifers fed DDT-containing forage indicates greater exposure of males on liver diseases.

During the lactation period, the first three months of postnatal ontogenesis are the most vulnerable, in which milk is the main component of the feeding ration (Lohakare et al., 2012). However, occurrence of DDT residues in other types of forage can also influence changes of thyroid and liver secretory activities in older animals. The average concentration of organochlorine in milk exceeded its level in other feeds by $2.33-3.11$ times. The level of thyroid hormones and activity of liver enzymes are interrelated with the concentration of DDT in animal feed, reflecting the effect of organochlorine pesticides on the functional activity of thyroid gland and liver in cattle depended on age and sex. In areas where DDT has been used extensively, animal feed should be thoroughly examined to exclude the presence of DDT residues because even in small amounts it can cause illness changes and damage of internal organs in the case of prolonged exposure.

\section{Conclusions}

Dichlorodiphenyltrichloroethane (DDT) contamination of feed contributes to hypothyroid in bulls and hyperthyroid in heifers of the AberdeenAngus cattle in long-term intake which is related to the competition for the receptors of the steroid hormones binding sites. DDT residues in feed caused disorders of liver activity reflected in the increase of liver enzymes secretion. Higher activity of most of the enzymes was noticed in heifers than in bulls, indicating that heifers of the Aberdeen-Angus cattle are more susceptible to liver inflammation as the result of DDT residues presence in feed. Milk, which is given to the calves at the beginning of the nursing period, should be especially examined for DDT residues occurrence because young animals are particularly susceptible to endocrine and liver disorders.

\section{References}

Al-Eryani L., Wahlang B., Falkner K.C., Guardiola J.J., Clair H.B., Prough R.A., Cave M., 2014. Identification of environmental chemicals associated with the development of toxicant associated fatty liver disease in rodents. Toxicol. Pathol. 43, 482-497, https://doi.org/10.1177/0192623314549960

Arroyo-Salgado B., Olivero-Verbel J., Guerrero-Castilla A., 2016. Direct effect of p,p'-DDT on mice liver. Braz. J. Pharmacol. Sci. 52, 287-297, https://doi.org/10.1590/S1984-82502016000200007

Aslam M., Rais S., Alam M., 2013. Quantification of organochlorine pesticide residues in the buffalo milk samples of Delhi city, India. J. Environ. Prot. 4, 964-974, https://doi.org/10.4236/ jep.2013.49111

Bozymov K.K., Abzhanov R.K., Akhmetalieva A.B., Kosilov V.I., 2012. Priority development of specialized beef cattle breeding - a way to increase the production of high-quality beef. News of the Orenburg State Agrarian University. 3, 129-131 
Brix K., Fuhrer D., Biebermann H., 2011. Molecules important for thyroid hormone synthesis and action - known facts and future perspectives. Thyroid Res. 4, S9, https://doi. org/10.1186/1756-6614-4-S1-S9

Calsolaro V., Pasqualetti G., Niccolai F., Caraccio N., Monzani F., 2017. Thyroid disrupting chemicals. Int. J. Mol. Sci. 18, 2583, https://doi.org/10.3390/ijms18122583

Colin I.M., Denef J-F., Lengele B., Many M-C., Gerard A-C., 2013. Recent insights into the cell biology of thyroid angiofollicular units. Endocr. Rev. 34, 209-238, https://doi.org/10.1210/ er.2012-1015

Du Y., Nomura Y., Zhorov B.S., Dong K., 2015. Evidence for dual binding sites for 1,1,1-trichloro-2,2-bis(p-chlorophenyl)ethane (DDT) in insect sodium channels. J. Biol. Chem. 291, 4638-4648, https://doi.org/10.1074/jbc.M115.678672

Engadahl J.N., Bignert A., Jones B., Athanassiadis I., Bergman A., Weiss J.M., 2017. Cats' internal exposure to selected brominated flame retardants and organochlorines correlated to house dust and cat food. Environ. Sci. Technol. 51, 3012-3020, https://doi.org/10.1021/acs.est.6b05025

European Commission Regulation (EC) No 149/2008 of 29 January 2008 amending European Commision Regulation No $396 / 2005$ of the European Parliament and of the Council by establishing Annexes II, III and IV setting maximum residue levels for products covered by Annex I thereto. O.J. 58

European Commission Regulation (EC) No 848/2018 of 30 May 2018. Document No. SANTE/11813/2017, Guidance document on analytical quality control and method validation procedures for pesticide residues and analysis in food and feed. (access: 08.02.2020 https://www.eurl-pesticides.eu)

Goldner W.S., Sandler D.P., Yu F., Hoppin J.A., Kamel F., LeVan T.D., 2010. Pesticide use and thyroid disease among women in the agricultural health study. Am. J. Epidemiol. 171, 455-464 https://doi.org/10.1093/aje/kwp404

Harada T., Takeda M., Kojima S., Tomiyama N., 2016. Toxicity and carcinogenicity of dichlorodiphenyltrichloroethane (DDT). Toxicol. Res. 32, 21-33, http://doi.org/10.5487/TR.2016.32.1.021

ISO 24333:2009, 2009. Cereals and cereal products-sampling

Kahl S., Bitman J., 1983. Relation of plasma thyroxine and triiodothyronine to body weight in growing male and female Holstein cattle. J. Dairy Sci. 66, 2386-2390, https://doi.org/10.3168/ jds.S0022-0302(83)82096-7

Kertz A.F., Hill T.M., Quigley J.D., Heinrichs A.J., Linn J.G., Drackley J.K., 2017. A 100-Year Review: Calf nutrition and management. J. Dairy Sci. 100, 10151-10172, https://doi. org/10.3168/jds.2017-13062

Kuba J., Tomza-Marciniak A., Pilarczyk B., Tarasewicz N., Pilarczyk R., Ligocki M., 2015. Comparison of DDT and its metabolites concentrations in milk from agricultural and industrial areas. J. Environ. Sci. Health B. 50, 1-7, https://doi.org/10.1080/03 601234.2015.964128

Leemans M., Couderq S., Demeneix B., Fini J.-B., 2019. Pesticides with potential thyroid hormone-disrupting effects: a review of recent data. Front. Endocr. 10, 743, https://doi.org/10.3389/ fendo.2019.00743

Lohakare J.D., Sudekum K-H., Pattanaik A.K., 2012. Nutrition-induced changes of growth from birth to first calving and its impact on mammary development and first-lactation milk yield in dairy heifers: a review. Asian-Australas. J. Anim. Sci. 25, 1338-1350, https://doi.org/10.5713/ajas.2012.12282

Lozowicka B., Abzeitova E., Sagitov A., Kaczynski P., Toleubayev K. Li A., 2015a. Studies of pesticide residues in tomatoes and cucumbers from Kazakhstan and the associated health risks. Environ. Monit. Assess. 187, 609, https://doi.org/10.1007/ s10661-015-4818-6
Lozowicka B., Kaczynski P., Wolejko E., Piekutin J., Sagitov A., Toleubayev K., Isenova G., Abzeitova E., 2015b. Evaluation of organochlorine pesticide residues in soil and plants from East Europe and Central Asia. Desalin. Water Treat. 57, 1310-1321, https://doi.org/10.1080/19443994.2014.996 008

Lozowicka B., Kaczynski P., Paritova A.E., Kuzembekova G.B., Abzhalieva A.B., Sarsembayeva N.B., Alihan K., 2014. Pesticide residues in grain from Kazakhstan and potential health risks associated with exposure to detected pesticides. Food Chem. Toxicol. 64, 238-248, https://doi. org/10.1016/j.fct.2013.11.038

Medica P., Cravana C., Ferlazzo A.M., Fazio E., 2020. Age-related functional changes of total thyroid hormones and glycosaminoglycans in growing calves. Vet. World 13, 681-686, https://doi.org/10.14202/vetworld.2020.681-686

Miles E.D., McBride B.W., Jia Y., Liao S.F., Boling J.A., Bridges P.J., Matthews J.C., 2015. Glutamine synthetase and alanine transaminase expression are decreased in livers of aged vs. young beef $s$ and GS can be upregulated by 17ß-estradiol implants. J. Anim. Sci. 93, 4500-4509, https:// doi.org/10.2527/jas.2015-9294

Mnif W., Hassine A.I.H., Bouaziz A., Bartegi A., Thomas O., Roig B., 2011. Effect of endocrine disruptor pesticides: A review. Int. J. Environ. Res. Public Health. 8, 2265-2303, https://doi. org/10.3390/ijerph8062265

Mrema E.J., Rubino F.M., Brambilla G., Moretto A., Tsatsakis A.M., Colosio C., 2013. Persistent organochlorinated pesticides and mechanisms of their toxicity. Toxicol. 307, 74-88, https://doi.org/10.1016/j.tox.2012.11.015

Mughal B.B., Fini J.-B., Demeneix B.A., 2018. Thyroid-disrupting chemicals and brain development: an update. Endocr. Connect. 7, R160-R186, https://doi.org/10.1530/EC-18-0029

Patisaul H.B., Adewale H.B., 2009. Long-term effects of environmental endocrine disruptors on reproductive physiology and behavior. Front. Behav. Neurosci. 3, 10, https://doi. org/10.3389/neuro.08.010.2009

Perera S., Lohsoonthorn V., Jiamjarasrangsi W., Lertmaharit S., Williams M.A., 2008. Association between elevated liver enzymes and metabolic syndrome among Thai adults. Diabetes Metab. Syndr. 2, 171-178

Reddy M.V.B., Reddy Y.R., 2015. Pesticide residues in animal feed and effects on animals and its products with special reference to endosulfan. Int. J. Res. Ayurveda Pharm. 6, 371-374, https://doi.org/10.7897/2277-4343.06372

Shrestha S., Parks C.G., Goldner W.S., Kamel F., Umbach D.M., Ward M.H., Lerro C.C., Koutros S., Hofmann J.N., Freeman L.E.B., Sandler D.P., 2018. Pesticide use and incident hypothyroidism in pesticide applicators in the agricultural health study. Environ. Health Perspect. 126, 097008, https://doi. org/10.1289/EHP3194

Snedeker S.M., 2001. Pesticides and breast cancer risk: a review of DDT, DDE, and dieldrin. Environ. Health Perspect. 109, 35-47, https://doi.org/10.1289/ehp.01109s135

Sormo E.G., Jussi I., Jussi M., Braathen M., Skaare J.U., Jenssen B.M., 2005. Thyroid hormone status in gray seal (Halichoerus grypus) pups from the baltic sea and the atlantic ocean in relation to organochlorine pollutants. Environ. Toxic. Chem. 24, 610-616, https://doi.org/10.1897/04-017R.1

Tebourbi O., Hallegue D., Yacoubi M.T., Sakly M., Rhouma K.B., 2010. Subacute toxicity of $p, p^{\prime}-D D T$ on rat thyroid: Hormonal and histopathological changes. Environ. Toxic. Pharm. 29, 271-279, https://doi.org/10.1016/j.etap.2010.03.002 
Turusov V., Rakitsky V., Tomatis L., 2002. Dichlorodiphenyltrichloroethane (DDT): ubiquity, persistence, and risks. Res. Rev. 110, 125-128

Yaglova N.V., Yaglov V.V., 2013. Changes in thyroid status of rats after prolonged exposure to low dose of dichlorodiphenyltrichloroethane. Bull. Exp. Biol. Med. 156, 760-762, https://doi. org/10.1007/s10517-014-2443-y
Zheng G., Han C., Liu Y., Wang J., Zhu M., Wang C., Shen Y., 2014. Multiresidue analysis of 30 organochlorine pesticides in milk and milk powder by gel permeation chromatography-solid phase extraction-gas chromatography-tandem mass spectrometry. J. Dairy Sci. 97, 6016-6026, https://doi.org/10.3168/ jds.2014-8192 